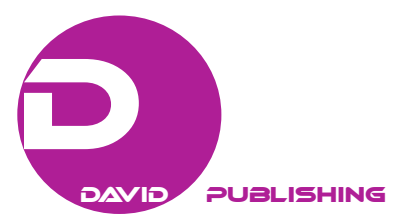

\title{
Perspectives for Reforming the European Banking System*
}

\author{
Octavian Ciobănaşu \\ Intesa Sanpaolo Bank Romania, Bucharest, Romania
}

\begin{abstract}
The global financial crisis, which started in 2007 to 2008 in the United States as the credit crunch crisis then spread to Europe, too and then took the form of the European Sovereign crisis, has shaken the foundations of the European banking sector. As a result, this crisis brought about discussions on what measures to take in order to reform the European banking sector and how the roles of the key players, such as the banks, the regulatory bodies, and the European Central Bank, should change in order to restore the health of the banking system and improve growth perspectives. This article will look at how this crisis can become an opportunity to rethink the old ways of doing things in the European banking sector, which have clearly become obsolete. A selection of specialized literature was analyzed for this research and revised with the personal experience of the writer from working in the banking sector.
\end{abstract}

Keywords: reforming the banking sector, financial crisis, development perspectives, European banking sector, capital markets, quantitative easing

\section{Introduction}

The European financial crisis has been looked into from many perspectives in the last few years by renowned economists, governments, regulators, banking managers and by the European Central Bank. There have been many points of view in regards to what measures should have been taken or still should be taken and each one of them was tested by the banking sector and by the financial markets.

At the beginning, it did not seem that the European financial crisis would be so long and so strong and have such a big impact on the economy of the European Union as a whole. Clearly, neither the European banks nor the European Central bank was prepared to deal with such a strong financial crisis.

In comparison to the United States, where the Federal Reserve bailed out large financial institutions then started a Quantitative Easing Program (QEP) spread over various years, the European Central Bank did not take at first such decisive measures. Instead, it chose to limit its actions and to declare that it would do all it would take to solve the financial crisis. With the arrival of Mr. Mario Draghi at the head of the European Central Bank, such strategy became the norm.

Only in 2015 did the European Central Bank decide to intervene by launching its own quantitative easing program of Euro 60 billion per month for at least 19 months, through which it would mainly acquire government bonds (Retrieved from http://www.economist.com/news/finance-and-economics/21640371

\footnotetext{
* The views expressed here are those of the author and do not necessarily represent or reflect the views of Intesa Sanpaolo Bank Romania.

Ciobănașu Octavian, Ph.D., Intesa Sanpaolo Bank Romania, Bucharest, Romania.

Correspondence concerning this article should be addressed to Octavian Ciobanasu, Sos. Mihai Bravu nr. 301, Bl. 18, Sc. A, Et. 8, Ap. 51, Bucharest, Sector 3, Romania. E-mail: octavian.ciobanasu@gmail.com.
} 
-policy-will-help-less-so-other-big-economies-better-late).

On one hand, it must be pointed out that the impact of the QE is different in Europe than in the US, due to the fact that in the US, the capital markets are more advanced and firms rely strongly on them, gaining benefit from the drop of yields on government bonds which motivated investors to seek other riskier assets like corporate bonds. On the other hand, in Europe firms depend more on banks than on other means of financing. At the same time, the European stock markets have expected the European Central Bank to start the QE program long before it was started and volatility had increased on any news regarding this topic. The turning point in the European Central Bank's strategy was the prospects of deflation throughout the EU, which was a rather scary perspective, considering the weak recovery of the European economies. Before the QE, however, the European Central Bank had adopted also other measures to fight the effects of the financial crisis, such as launching Longer Term Refinancing Operations (LTRO) to stimulate the banks to restart lending to the real economy. However, right now, the European banks have rather high liquidity compared to the lending needs. Therefore, there are other problems which must be solved in order to restore the health of the European financial system. In this research, a wide range of literature and studies were analyzed in order to make the best recommendations to solving these problems. In addition, the personal direct professional experience of the writer was used to improve these recommendations. The subject analyzed is very dynamic and while there are other studies and articles dealing with this subject, the situation is changing constantly, needing an update and improvements in the recommendations on how to reform the European Banking Sector.

\section{The Solutions Needed for the European Banking Sector}

The European Central Bank clearly has extended its role in the European banking system after starting to take over the supervision of the largest banks in Europe while leaving the task of supervising the smaller banks to the local national central banks of the single European countries. Its conventional and unconventional measures have had their effect, but there is still more to be done.

The actions of the European Central Bank need to be accompanied by political consensus in order to succeed. Local governments must also take action in order to further stabilize the markets and their economies through the implementation of structural reforms and by putting in order their government finances (Weistroffer \& Peters, 2012).

The European Central Bank stressed this point even two years earlier when stating that,

The European Central Bank's liquidity support for the banking sector cannot replace the measures that need to be taken by national governments, regulatory bodies and the financial sector itself to ensure the solvency of individual banks and the sustainability of the banking sector's business models, also at higher interest rates. (European Central Bank, 2011, p. 68)

The European financial sector is different from that of the US and as such, identical measures such as those of the Federal Reserve cannot be applied. The US functions as one body, while the European Union is not as well integrated from a financial point of view.

In the US, there are more ways for the companies operating in the economy to obtain financing other than banks, while in Europe, it is pretty much the only way for the economy to function. Therefore, European banks are valuable intermediaries for now.

The measures adopted by the European Central Bank in response to the financial crisis included non-standard monetary policy measures (Thimann \& Winkler, 2013), besides the reduction in the key interest 
rate, as mentioned earlier. The non-standard measures have been implemented through the existing structure of the operational framework in order to support the banks having difficulty to rise funding, so that they continue to provide sufficient credit to the private sector, while containing the risk of contagion in the financial sectors (European Central Bank, 2011).

As a matter of fact, in the last three years leading up to 2015, the measures adopted by the European Central Bank and by the Federal Reserve have created unrest in the financial markets. Every declaration from the officials of these two important central banks was heard by investors and left an impact in the US and European financial markets.

In 2015, the European Central Bank finally launched its QEP with a clear target to prevent a deflation outburst in the EU, through the acquisition of sovereign bonds (Cosgrave, 2015). The program involves a 60-billion-euro per month bond buying program for 19 months, until September 2016. It has ambitious goals and so far it has had both direct and indirect effects. It has stabilized the European financial markets and has limited the impact of a possible Greek exit from the EU (Grexit). Without the QEP, the situation would have been much worse.

In regards to the European crisis, Krugman (2012) presented some solutions for solving the problems that it generated:

- Stop panic attacks and guarantee liquidity through government bond purchases by the European Central Bank of the Euro nations;

- The European countries running high deficits need a path to become competitive again (surplus countries need to buy products from deficit countries exports);

- There is a need for an expansionary monetary policy and fiscal stimulus in Germany and in a few smaller countries;

- Costly deflation in deficit countries will need moderate inflation in surplus countries over time (3\% or $4 \%)$.

The current paper findings agree with these solutions compared to the traditional perspective of austerity and reforms for a number of reasons. First, this solution acknowledges that there are countries with different speeds in Europe and the slower ones should be helped to make up for the difference. Second, austerity measures by themselves only deepen the economic troubles in a troubled economy. Third, the panic attacks that have taken place in the stock markets have done more damage to the recovery than the crisis itself, since these attacks have had the effect of a magnifying glass. Fourth, considering that some countries in difficulty have a hard time recovering since they are using the euro currency, alternative methods must be used to help them inside the EU.

\section{Development Perspectives in the European Banking Sector}

In regards to the future of the European banking sector, there are quite a few things to be taken into consideration. This paper must consider Europe from an institutional, economic, political, and regulatory point of view in order to have a clear picture of how the banking system will recover from the financial crisis and from here on and how it will develop.

The current institutional measures and reforms have not done enough to solve the difficult situation the banks are in. This is not to say that they are on the brink of collapse, but they are not in such a healthy condition as to start financing the private sector and the real economy. 
As a matter of fact, this situation seems similar to the one the Asian banks were in the previous Asian crisis of 1997-1999 (Lybeck, 2011): The banks were too weak to lend money but not as weak as to fail (Krugman, 2009). The Japanese banks were financially weak and it took a long time for the government to draw up a $\$ 500$ million rescue plan.

This situation went on for years with the banks in a suspended state. Obviously, this cannot be good for the economy which desperately needs financing from the financial sector, especially in Europe where other means of financing are not as readily and easily available as in the United States.

The European Union does not have a single government, nor does it have a common fiscal policy. As a matter of fact, it is rather heterogeneous if they look at the countries that use the euro currency. This has become obvious with the financial crisis, since it has exacerbated all these differences.

It cannot be said that the financial crisis is over, but there is a hope that the worst has passed. It is certainly a moment of reflection on those things that need to be changed. For the moment, the European banks have undergone stress tests which determined which of them have capital shortfalls and have taken measures to correct those issues. From now on, they need to concentrate on growing business. Unfortunately, the European perspectives in terms of economic growth are not so optimistic, since there is always the risk of deflation and lack of growth in the short to medium term.

Europe should try to become more homogeneous in terms of approach towards the banking sector, meaning better supervision (Bernhard, 2011), better regulation, and improved reaction speed. Europe needs to become more flexible towards the banking and economic sector and learn the good parts from the US, such as in the area of entrepreneurship. It must avoid at all costs over eurocracy (Craig \& Elliott, 2009), since there is the risk of over regulating too many sectors instead of creating a dynamic European market and growth throughout the EU countries.

In order to try and figure out the perspectives of the banking sector, this paper needs to also look at other factors. There are opportunities to be sought if the euro currency continues to lose value, since this will stimulate exports. Decreasing oil prices and the uncertainties of economic growth around the world and in China are putting pressure of the financial markets and swaying investors from putting their money in Europe.

The main goals of the European Union should be to create economic growth, improve employment, especially among the younger generations, and become more united and efficient (Teece, 2009). They do not need further reminders besides the financial crisis that things need to change, also in the banking sector. The reform in the banking and financial sector has to continue in order to make these activities safer and more trustworthy.

\section{Reforming the European Banking System}

There are more ways than one to bring change to the European banking system as well as to the whole banking system. However, the changes must be made towards the right direction and they must be made from two levels: at the level of the whole banking system and at the level of individual banks.

As far as the general approach is concerned, the most acclaimed measure is the establishment of a European Banking Union.

Given the economic troubles of the European financial system, it has become obvious that the European banking sector is fragmented and therefore it is hard to implement global policies and measures in the whole system. As a result, the constitution of a European Banking Union might be a solution. The implementation of 
such measure implies that there should be a centralized banking supervision for the banks of all member states, rather than having national supervision.

As people were able to see in many situations in Italy, Spain, and Greece, the problems affecting the banks also affect the governments and vice versa. If the banks are in trouble or there is the risk of collapsing, then the government might intervene (especially for systemic financial institutions - too big to fail) with bailouts. Likewise, if the government is in trouble and in need of financing, the banks can intervene acquiring government bonds (and not necessarily to help, but because the increase in interest rates due to higher risk makes them attractive). In any case, both the banking sector and the government become destabilized.

The European Banking Union has the improvement of supervision activities, smoother coordination of banking measures, and better coordination in case of difficult market conditions as objectives. The European Banking Union has started to be implemented in January 2013 and will continue until 2018.

The idea of a Banking Union seems practical at the concept level, considering its ambitious objectives. However, the way in which it will be implemented will count very much.

As of now, it is hard to say to what extent the Banking Union will be successful, considering the fact that the European Union is so fragmented. Perhaps there should also be a Political Union and a Fiscal Union in addition to the Banking Union. The Monetary Union and Banking Union just are not enough. According to CESifo Forum,

The euro zone is atypical as an economic union because monetary policy is decided at the central (European) level while fiscal policy is mostly carried out at the sub-central (member state) level. Therefore the view is widespread that there are just two options for the future of the euro zone - either it is complemented by a fiscal union, or it will fall apart. (Retrieved from https://www.cesifo-group.de/DocDL/forum1-12-gesamt.pdf)

This raises many questions of how much power member states are willing to give up for a common objective.

The success of the Banking Union depends on reaching common grounds on who holds the power and makes the decisions and who follows their implementation. Will the National States and Central Banks be willing to give up control and to what extent?

The Basel III Accord has started to be implemented in January 2013 and the implementation process will go on until 2018. The third version of the Basel accord comes after the implementation of Basel I and II but with tighter capital requirements, more stress tests on banks, and more on market liquidity risk.

These measures are meant to guarantee the stability of banks in case the market conditions turn bad or some fail. The fact that the implementation of tighter capital requirements on European banks was postponed until 2015, gave the banks a moment to breathe and the markets space to applaud this measure with a wave of acquisitions that drove the value of the shares of financial institutions up.

However, the implementation of this accord will continue to have strong impact on the whole financial system worldwide in the following years. People have to keep in mind though the tighter capital requirements will change banking from now on. This means that in order to lend money, banks must put aside a considerably higher amount of money than before. Therefore, they will be able to lend less money than they previously did but they will supposedly be safer.

\section{Recommendations for Europe}

Europe has still many issues to clear in order to get out of the financial crisis and restore growth. The 
European institutions must change their ways and become much more dynamic and quick in taking action. More power should be given to the European Central Bank in order to guarantee the stability of the European banking system.

The European countries and its institutions were not as swift as the United States in taking measures for the financial crisis. It took a while for European officials to evaluate the extent of the problem and to actually start to talk about what to do. This took way too long and allowed the crisis to deepen, banks to struggle, investors to flee, and financial markets to drop.

Being one of the most powerful economies in the world and the country that was least affected by the crisis, Germany has taken the leadership of the European effort to restore the health of the European economies and the euro. It took the initiative to determine European countries on the brink of default to take measures to cut their spending by restructuring the public sector, cut government spending in general, and also generalize austerity measures throughout the whole economy.

The most affected countries were Greece and Cyprus. These two countries had the highest debt and had to be bailed out by the so-called Troika (International Monetary Fund, European Commission, and European Central Bank). In the case of Greece, the conditions required for unblocking the lifesaving (from default) financial tranches of the bailout package were harsh. People took to the streets, the government passed on the austerity measures, and the tranches were paid.

In Cyprus, there was a particular situation with the banking system being much larger than the economy; it was considered as a fiscal safe haven. As such, the Troika requested an unusual measure from the government in order for it to unblock the bailout tranche. That measure was to tax depositors with deposits above 100k euro, believing that many above that sum have gained the money avoiding to pay taxes in their countries. This was more of an experiment and created unrest on the financial markets, especially in Europe. The prospect of having this measure applied in other EU countries was frightening and it had nothing in common with capitalism and the freedom of ownership. It just punished everyone regardless of their standing and the origin of their funds.

Yet another problem that must be solved in Europe regards entrepreneurship. This issue applies to most European countries and is a major issue compared to the US where entrepreneurship is encouraged more (Retrieved from http://www.economist.com/node/21559618). In Europe for instance, once entrepreneur fails in one business venture, most of the time he will not be able to open another business activity or will not be able to hold a bank account for a number of years. The author understanded that fraudulent behavior must be punished, but a sincere business attempt should not be discouraged. If this paper looks at many successful companies in the US, it will see that many of them were the result of many attempts to start a successful business by their entrepreneurs, which eventually succeeded. Such approach should be adopted also in Europe, with all due precautions. Entrepreneurial activity should be encouraged more, since it leads to growth and progress and increases employment.

\section{References}

Bernhard, S. (2011). Financial supervision in the EU-Incremental progress, success not ensured. Retrieved from http://www.dbresearch.in/PROD/DBR_INTERNET_EN-PROD/PROD0000000000276501/Financial+supervision+in+the+E $\mathrm{U} \% 3 \mathrm{~A}+$ Incremental+progress,+success+not+ensured.pdf

Cosgrave, J. (2015). ECB emphasizes commitment to bond-buying plan. Retrieved from http://www.cnbc.com/2015/04/02/ecb-emphasizes-commitment-to-bonding-buying-plan.html 
Craig, D., \& Elliott, M. (2009). The great European rip-off. London, UK: Random House Books.

European Central Bank. (2011). The ECB's non-standard measures-Impact and phasing out. Retrieved from https://www.ecb.europa.eu/pub/pdf/other/art1_mb201107en_pp55-69en.pdf

Fuest, C., \& Peichl, A. (2012). European Fiscal Union: What is it? Does it work? And are there really no alternatives? Retrieved from https://www.cesifo-group.de/DocDL/forum1-12-gesamt.pdf

Krugman, P. (2009). The return of depression economics and the crisis of 2008. New York, NY: W.W. Norton \& Company.

Krugman, P. (2012). End this depression now. New York, NY: W.W. Norton \& Company Inc.

Lybeck, J. A. (2011). A global history of the financial crash of 2007-2010. New York: Cambridge University Press.

Teece, D. J. (2009). Dynamic capabilities \& strategic management. New York: Oxford University Press.

The Economist. (2012). European entrepreneurs: Les misérables-Europe not only has a euro crisis, it also has a growth crisis. That is because of its chronic failure to encourage ambitious entrepreneurs. Retrieved from http://www.economist.com/node/21559618

The Economist. (2015). Quantitative easing in the euro zone: Better late than never-The policy will help, but less so than in other big economies. Retrieved from http://www.economist.com/news/finance-and-economics/21640371-policy-will-help-less-so-other-big-economies-better-late

Thimann, C., \& Winkler, P. (2013). The ECB's non-standard monetary policy measures: The role of institutional factors and financial structure. Retrieved from: http://www.ecb.europa.eu/pub/pdf/scpwps/ecbwp1528.pdf

Weistroffer, C., \& Peters, H. (2012). Talking point: "Three-year refinancing operations: ECB kills two birds with one stone”. Retrieved from https://www.dbresearch.com/PROD/DBR_INTERNET_EN-PROD/PROD0000000000286392.pdf 